\title{
MAGNETIC MODELLING TO PREDICT VOLUME OF BASIN AS A PRELIMINARY STUDY IN NORTH CIREBON
}

\author{
Fuad Aulia Bahri, Muhammad Arif Budiman
}

Geophysical Engineering, Faculty of civil engineering and planning, Institut Teknologi Sepuluh Nopember

fuadbahri08@gmail.com,muh.arifbudiman0@gmail.com

\begin{abstract}
Abstrak. Salah satu metode eksplorasi hidrokarbon adalah metode magnetik. Metode magnetik berguna untuk mengetahui nilai anomaly magnetik batuan di bawah permukaan. Nilai magnetik yang digunakan adalah nilai magnetik yang disertai dengan nilai IGRF sehingga memiliki nilai anomaly magnetik yang dihasilkan oleh cekungan. Nilai anomaly magnetik rendah mengindikasikan terdapatnya cekungan dengan kisaran nilai $44.800 \mathrm{nt}-44.400 \mathrm{nt}$. Tujuan penelitian ini yaitu untuk menganalisa suatu cekungan serta mampu memprediksi besar volume basin berdasarkan peta anomaly magnetik.

Metode penelitian ini dengan cara melakukan slicing 8 line pada peta anomaly magnetik sintetik yang diindikasikan sebagai cekungan. Hasil slicing diolah secara forward modelling pada software MAG2DC. Didapatkan nilai parameter berupa nilai bearing, pusat bodi, lebar maksimum, kedalaman, serta nilai susceptibilitas cekungan $(-0,02)$. Lakukan semua pekerjaan hingga semua line. Data data yang didapat kemudian di integrasikan dalam Software AutoMAX3D / AutoCad3D. Kemudian dilakukan analisis cross section dari setiap line. Didapatkan bentuk cekungan secara 3D yang memiliki volume sebesar 0.146 triliar meter kubik.
\end{abstract}

Kata Kunci: Cekungan, Magnetik, Susceptibilitas.

Abstract. One of geophysical methods as for hydrocarbon exploration is magnetic method. This method is used to find out about the value of magnetic anomaly under the surface. As the references, the value of magnetic that we used is the value data from IGRF (International Geomagnetic Reference Field) and it would indicate a basin if the value are negative around (44.400 $\mathrm{nt}-44.800 \mathrm{nt}$ ). As for goal of this research is to analyze geological basin and to predict total volume of basin based on magnetic anomaly map.

This research started by making a slice on magnetic anomaly map up to 8 times. Then, the result is processed in forward-modelling on MAG2DC. As the result, we got some parameter like the value of bearing, central body, maximum width, depth, and the susceptibility of basin. After that, all the datas are combined on AutoCad3D/AutoMax3D to analyze cross-section on every line. The final result is a geometry model of $3 D$ basin that has a volume value of 0.146 trilion cubic meters.

Keywords: Basin, Magnetic, Susceptibility.

\section{INTRODUCTION}

Geomagnetic as a geophysical survey is the oldest method in both the hydrocarbon and mineral exploration. This method has been known for more than three centuries ago. The philosophy of this method is that the Earth has a strong magnetic field. Magnetometer is an instrument to measure the magnetization of the rocks, this instrument records the relative differences between various rock magnetization to the magnetic field of the earth.

As an early phase of hydrocarbons exploration, geomagnetic method is intended to determine the value of susceptibility of rocks. These value of susceptibility are very useful to know the basic configuration of the rocks. This theory is possible since there are the differences between the magnetic properties of sedimentary rocks (overburden) with bedrock which is igneous or metamorphic. Furthermore, from these value of susceptibility, they can also know where the base depth is. And if the value of susceptibility were small, it would indicates basin.

\section{MEHTODOLOGY}

The methodology used is by making some slices on the magnetic anomaly map which 
suspected basin in the sea north of Cirebon with the coordinates as follows:

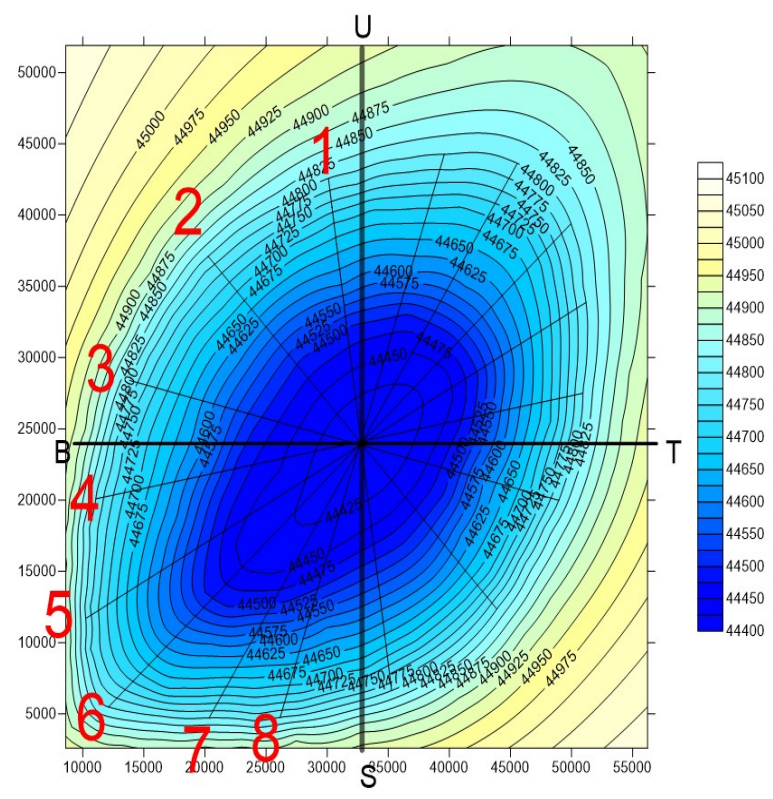

Picture. 1 : Magnetic Anomaly Map.

Then, the slicing data are entered into the software of mag2dc to get the value anomaly below the surface. The output data will obtained in the form of bearing, the central body, maximum width, depth, and the susceptibility of basin. After that, the data is integrated in the software of autocad/AutoMax to obtain shapes like geometry.

The steps of data interpretation from Mag2DC and writing this research are shown as follows:

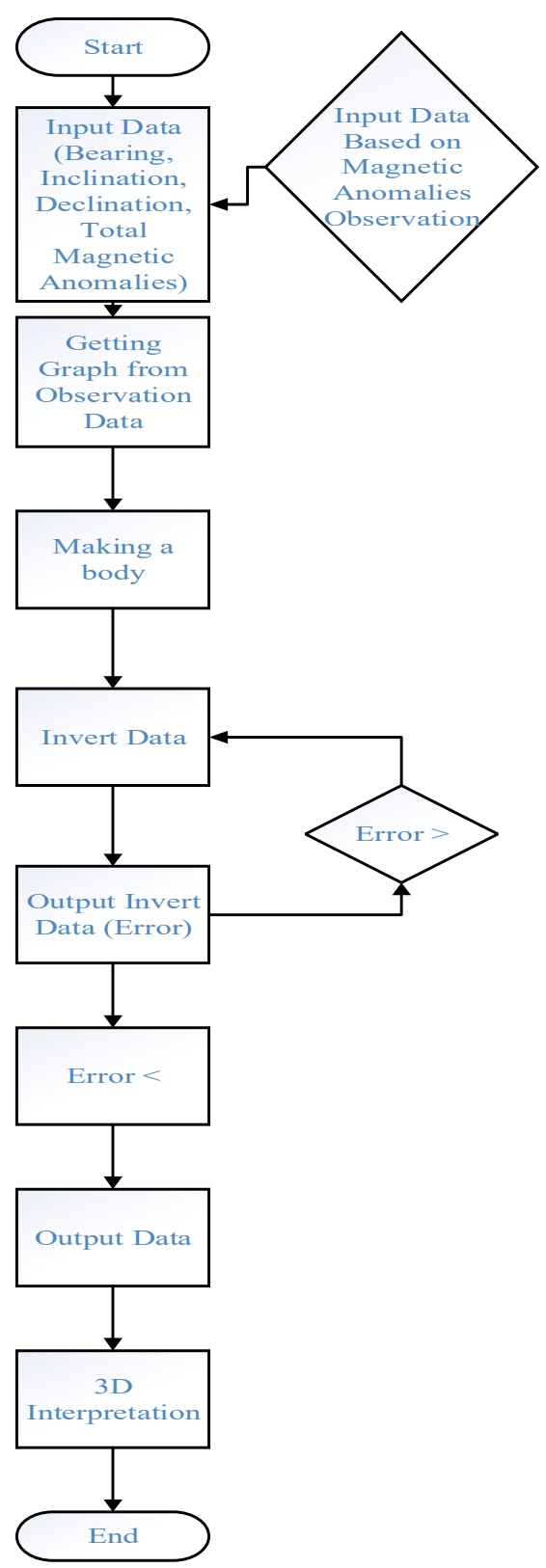

Picture. 2 : The Steps of Data Interpretation from Mag2DC 


\section{RESULT AND DISCUSSION}

After doing slicing, the data are obtained and are put into software of mag2dc. From Mag2dc software, all the models that are obtained have a value of susceptibility 0.4 (sediment, sandstone) with details of the parameters as follows:

Tabel 1. Parameter That Are Obtained From Mag2dc Software

\begin{tabular}{|r|r|r|r|r|r|}
\hline $\begin{array}{c}\mathrm{Li} \\
\text { ne }\end{array}$ & Error & $\begin{array}{c}\text { Central } \\
\text { Body(m) }\end{array}$ & $\begin{array}{c}\text { Depth } \\
(\mathrm{m})\end{array}$ & Width (m) & $\begin{array}{r}\text { Susep } \\
\text { tibilit } \\
\mathrm{y}(\mathrm{SI})\end{array}$ \\
\hline 1 & 121.32 & 17196.46 & 407.22 & 35443.226 & 0.4 \\
\hline 2 & 138.42 & 16777.46 & 536.08 & 33580.009 & 0.4 \\
\hline 3 & 92.4 & 20505.81 & 494.85 & 35719.640 & 0.4 \\
\hline 4 & 54.86 & 20668.9 & 489 & 39844.556 & 0.4 \\
\hline 5 & 181.76 & 22950.78 & 505.8 & 46028.230 & 0.4 \\
\hline 6 & 145.45 & 26542.42 & 391.44 & 50155.092 & 0.4 \\
\hline 7 & 85 & 22508.09 & 391.75 & 45488.111 & 0.4 \\
\hline 8 & 77.38 & 20065.81 & 0.4 & 40276.403 & 0.4 \\
\hline
\end{tabular}

After that, AUTOCAD were used to make a 3D shape model:

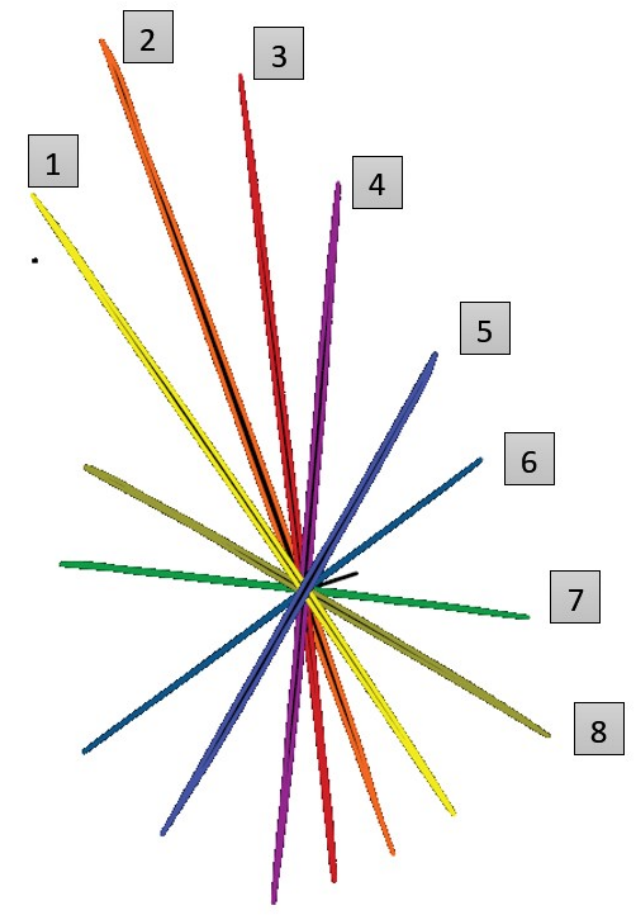

Picture. 3 : Basin Model on AUTOCAD

Model with 3D shaped, if we visualize it like flat pyramid where the bottom side is bigger than the top side. In a glance, it indeed shapes flat because it is affected by ratio between length and depth that is quite far.

The volume calculation is likened basin like a quadrangle pyramid where the upper end is cut off. Other than that, calculation is done globally to make it easier in calculating.

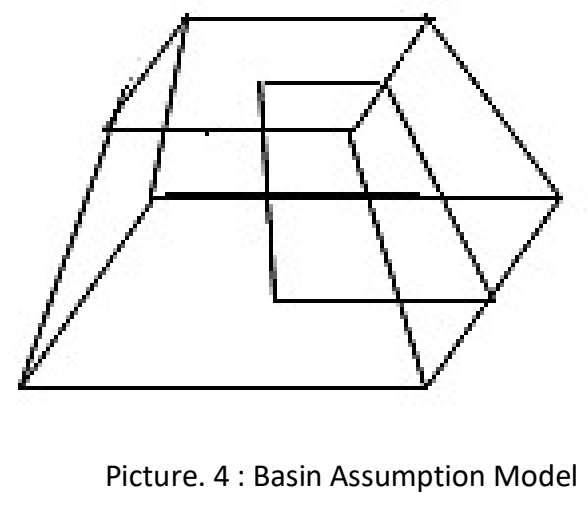

The basin assumption model above is $2 / 3$ part of the volume of pyramid. This is because the shape of the basin that looks flat (the picture above is peaking up. It is possible that the missing top part is $1 / 3$ volume part of the pyramid):

Volume of pyramid: $1 / 3 \times$ base area $x$ height So that:

Volume of basin $=2 / 3$ Volume of pyramid

By assuming that the outer shape of the basin is a rectangle, then:

Volume of basin $=2 / 9 \times$ Length $\times$ Wide $\times$ Height

From the model, we also get results as follows:

$\begin{array}{lll}\text { Length } & =50630.818 & \mathrm{~m} \\ \text { Wide } & =33808.756 & \mathrm{~m} \\ \text { Height } & =386 & \mathrm{~m}\end{array}$

Then, if we input the number into the equation, we'll get the value as follows:

$$
\text { Volume } \quad \begin{aligned}
& =2 / 9 \times 50630.818 \mathrm{~m} \times \\
& 33808.756 \mathrm{~m} \times 386 \mathrm{~m} \\
& =0.146 \times 1012 \mathrm{~m}^{3}
\end{aligned}
$$

Thus, the results of research conducted found the volume of the basin is 0146 trillion cubic meters. 


\section{Conclusion}

In the analysis of large volumes of body that is assumed with a truncated-peak-pyramid shape has a volume value of 0.146 trilion cubic meters.

It also obtained from drawing line on the magnetic anomaly maps of eight lines that acquired eight body on mag2dc software at a price of Susceptibility 0.4 . Susceptibility price is included in the sediment rocks, sandstone. Also, average body at 400 meters depth from the surface has a depth range of 386 meters.

\section{Suggestion}

For a better result and interpretation, this result will need further investigation from other geophysical data such as 3D seismic data and wireline logging.

\section{Bibliography}

Telford, W.M, L.P. Geldart and R.E. Sheriff. 1990. "Applied Geophysics, 2nd Edition". Cambridge.

Dwi K, Ilham. 2002. “Eksplorasi Geofisika dengan metode Magnetik untuk identifikasi awal cekungan minyak di perairan utara Cirebon", Tugas Akhir Teknik Kelautan. Institut Teknologi Sepuluh Nopember. 